\title{
Empirical Evidence Concerning Smes' Corporate Websites: Explaining Factors, Strategies and Reporting
}

\author{
Amalia García-Borbolla. University of Cádiz. Spain \\ amalia.borbolla@uca.es
}

Manuel Larrán. University of Cádiz. Spain

manuel.larran@uca.es

Rafael López. University of Cádiz. Spain

rafael.lopez@uca.es

\begin{abstract}
The important role played by Small and Medium-sized Enterprises in any contemporary economy as a motive force for generating employment and wealth is universally acknowledged and therefore this work is based upon a more detailed study concerning the efficiency of SMEs. Therefore by analysing a sample of 816 SMEs, we aim to study the information published on their Websites in order to clarify certain doubts with respect to the type of target users and thus discover the objectives and strategies pursued by publishing a corporate Webpage. Given the low observed percentage of SMEs with a Website $(31.74 \%)$ we have also studied the factors influencing the propensity of businesses to possess a corporate Website.
\end{abstract}

Key words: Corporate Website, Voluntary Disclosure, SMEs. 


\section{INTRODUCTION}

In the same manner as computers in their day had a large impact upon the transformation of small businesses, if indeed everything that has been said regarding the virtues of an Internet presence for small businesses is to be believed, the Internet now appears to be the new technology that will transform business (Howard, 1996). It would appear that official organisms are convinced of this fact given the existence of numerous initiatives that tend to promote the use of the Internet among SMEs. In this regard, Poon and Swatman (1995) analysed governmental policies in countries that enjoyed a good level of Internet connectivity and found that all were encouraging small businesses to use the information highways in order to make them more efficient and effective in global competition.

However it is also true that it is still difficult to identify direct benefits to justify the costs of maintaining a Website (Poon and Swatman, 1997) yet, as Porter (2000) indicates, the Internet can be a critical factor in the improvement of a business' commercial success and in its operating efficiency. Other authors suggest that there are additional advantages that range from the recruitment of personnel to improving management and productivity. It is worth noting with respect to SMEs that Internet-based technologies provide them with a chance to overcome the obstacles of size and enable them to compete more effectively and/or to compete in larger markets (Dholakia and Kshetri, 2004); moreover, there is evidence to suggest that the Internet has increased international opportunities for SMEs (Hamill and Gregory, 1997; Lituchy and Rail, 2000).

Undoubtedly not all businesses are going to reap the same benefits from the Internet $^{1}$ and therefore businesses must decide whether the above advantages outweigh the potential difficulties, costs or risks (Walczuch, Van Brave and Lundgren, 2000) that having a Website might entail. Among the main obstacles are the costs of creating and maintaining a Website and the possible strategic risk involved, this risk being the potential use of the published, mainly commercial, information by competitors in order for them to gain a competitive advantage (Babio, Muiño and Vidal, 2001]. In this regard it is worth noting that the information published on businesses' Websites is of a voluntary nature since with

\footnotetext{
${ }^{1}$ As already stated by Porter and Millar (1985) businesses whose products and value chain are of low informational intensity will have a lower possibility of developing the Web's potential.
} 
the exception of companies that are quoted on certain stock markets ${ }^{2}$, there is no regulation obliging businesses to have a Website and even less for them to publish information on it.

With respect to the decision to incorporate new technologies into a business, Information Systems researchers have suggested social psychology intention models as a theoretical basis for studying the determinants of user behaviour. Fishbein and Azjen (1975) developed a general theory of behaviour based on the idea that human beings process information and use it systematically, it thus being called the Theory of Reasoned Action (TRA).

This theory integrates a group of variables related to decision making at a behavioural level and has been successful in predicting and explaining behaviour in a variety of domains. TRA is highly appropriate for studying the determinants of computer use behaviour. However, it is perhaps too general to explain the case under study here.

Davis introduced an adaptation of the above theory and in 1989 created his Technology Adaptation Model (TAM) which is used especially to explain computer use. TAM uses the preceding theory as the theoretical basis for specifying causal relationships between various premises: Perceived Usefulness (the degree to which an individual believes that adopting one particular technology will improve the performance of his or her work) and Perceived Ease of Use (the degree to which an individual hopes that working with a particular technology will be easy to use both in terms of physical and mental effort). This Theory is regarded as being more specific and is designed to be applied solely to computer use, but given the fact that it incorporates the accumulated observations of a decade of studies, it can be adapted to model the acceptance of other technological elements.

Azjen's (1991) Theory of Planned Behaviour (TPB) complements the TAM Theory and assumes that behaviour is determined by the intention of achieving the desired behaviour. The intention or decision of an executive concerning innovation, in our case the creation of a Website, is a function that is determined by three factors:

\footnotetext{
${ }^{2}$ Which must adapt themselves to the regulations applied by their respective governing bodies, the CNMV, TSE, $\mathrm{COB}$, etc., concerning the publication of information on their corporate Websites.
} 
- (A) Attitude, assumed as the sum of a series of beliefs with regard to the negative or negative consequences of innovation.

- (SN) Subjective Norm or the degree to which the executive perceives social pressure for having an Internet presence.

- (PBC) Perceived Behaviour Control. Understood to be the greater or lesser ease with which an executive believes the innovation will be adopted, including potential obstacles.

In recent years, these theories have been applied with a certain degree of assiduity, but in some cases they have been applied with a lack of structuring and in others using unsuitable and imprecise measurements of explanatory variables, based fundamentally on the decision-makers' perceptions, thus leading researchers to use a heterogeneous range of measurements. The above might be justified by researchers attempting to adapt the measurements used to the particular characteristics of the phenomenon under study. These characteristics range from the adoption of computers (Igbaria, Zinatelli and Cragg, 1997) or any other Information Technology (Harrison, Mytkyn and Riemenschneider, 1997; Lal, 1999), the adoption of e-commerce (Lal, 2002; Grandon and Pearson, 2004; Michandani and Motwani, 2001), the adoption of EDI ${ }^{3}$ (Chwelos, Bensabat and Dexter, 2001; Iacovou, Bensabat and Dexter, 1995; Kuan and Chau, 2001) and to the adoption of the Internet (Cragg, 1996; Mehrtens, Cragg and Mills, 2001).

According to some authors, this variability has given rise to an incomplete state of knowledge concerning the implantation of Information Systems (Davis, 1989; Kwon and Zmud, 1987). Given this situation some authors (Thong, 1999) suggest the adoption of integrated models that include all of the evidence gathered previously, although it is true that more research must be undertaken in this line in order to identify the critical factors affecting the adoption of a specific technology.

\footnotetext{
${ }^{3}$ Electronic Data Interchange.
} 


\section{BUSINESS STRATEGY AND THE USE OF THE CORPORATE WEBSITE}

Given the fact that one of the goals of this study is to analyse what type of users are the basic target audience of an SME's Website, and therefore what their objectives are when doing so, we will now briefly examine the different strategies that businesses habitually employ with regard to their corporate Websites.

Although recent works have established new points of view focusing upon the degree of a business' Internet evolution (See Teo and Yujun, 2004), for our purposes we have chosen to present the typology of Websites employed based on the strategy pursued by the businesses (Sparkes and Thomas, 2001; Geiger and Martín, 1999; Ellis-Chadwick, Doherty and Hart, 2002), establishing three options that might be "plausible" from a business point of view once the decision to adopt a Website has been taken.

\subsection{Ornamental Web presence}

Here the information provided could essentially be classified as Corporate Information or General Publicity (Cheung and Huang, 2002; Liu et al., 1997) giving general global information concerning the business. Even though some more specific information is provided (strategies, management intentions, objectives, market shares, forecasts, the company's shares, Human Resources, financial notes etc.), this information will always appear as promotional information.

This type of information does not have a specific target audience; rather its aim is to present a general picture to all types of users. The Internet is used by companies for what could be regarded as a formal presence. They feel that they must be present on the Web, but they do not pursue any specific objectives, something that is in all probability motivated by one of the following factors:

- An imitative or mimetic effect inspired by the novelty of innovation. Businesses do the same as their competitors.

- It is an attempt by businesses to incorporate an air of modernity into their organisational structures (Bonsón and Escobar, 2002), something that previously happened with computers. 
- Web Address. Many businesses establish themselves on the Internet simply due to the fact that it appears to be a sine qua non for credibility, the same as a fiscal address was in the past. $\mathrm{Ng}$ (1998) notes that it might equally be due to the fact that they want to establish their presence for when the Web becomes a more powerful tool.

The Websites of such businesses would be simply one or a few pages, giving little more than self-evident data and will updated infrequently Geiger and Martín, 1999). We believe therefore that this is a group of businesses that have no clear vision of the benefits that this new medium and the Web might bring them. The existence of such a Website does not obey a clear strategy or is not even a part of that strategy and therefore the businesses' basic aim is to show that they do have Internet activity.

\subsection{Informational Web presence}

This group includes those Websites that although they might also contain corporate information, also have a section dedicated to a certain interest group towards which specific information is directed. This group is therefore distinguished from the above fundamentally by the volume of information provided and the orientation of this information towards a specific user group, principally present or potential clients.

Such Websites usually include virtual versions of leaflets that exist in other media and therefore the website is simply being used to provide users with an additional means of obtaining information yet without suitably adapting this information to the new medium and thus making better use of the potential provided by the Internet.

\subsection{Relational Web presence}

In spite of Huizingh's (2000) statement that "the basic aim of a Website is to provide information", some businesses, aware of the qualitative leap that interactivity represents, establish two-way communication. This third strategy recognises the Internet as a medium that radically changes the rules of play and one that is perceived as a tool enabling relationships to be built up and maintained 
with Website users. Therefore in this case the use of the Internet will be integrated into these businesses' strategic plans.

As well as containing information about the businesses, this type of corporate Website will also provide information that does not concern the business but which is of interest to its users. It will also be a means for the business to obtain feedback through asking users for their opinions and suggestions as well as providing them with electronic newsletters, forums and news.

\section{EMPIRICAL STUDY}

\subsection{Introduction}

The empirical study presented is structured into two stages. In the first stage we will perform a descriptive analysis that will analyse the type of information published on SME's corporate Websites in order to identify the type of target user for the published information, and as a result the goals pursued by the published information. On the other hand, and given the high percentage of businesses that do not possess a Website, our next aim is to identify the variables that might possibly influence the decision to implant a corporate Website.

For the first of the two aims, we drew up a range of possible content that businesses might include on their Websites. To do this, we adapted the items established by Larrán and Giner (2002) taking into account the different nature of the sample under study (Table 1).

Although it would be interesting to identify and assign the different items to the possible stakeholders ${ }^{4}$ or information users, given the complexity and high degree of subjectivity that this would entail, we have opted to classify them as a function of the nature of the information and have therefore established the following information categories: (1) Corporate or General Information - a basic item of the ornamental strategy, (2) Corporate, (3) Financial, (4) Strategic, (5) Labour and (6) Environmental.

\footnotetext{
${ }^{4}$ According to Clarkson (1995), stakeholders are people or groups that have or demand similar rights or interests.
} 
In order to take into consideration the possibility that some businesses not only provide users with information but that they might also be in a higher model, we included some items that represent the businesses' intention to achieve more intense, permanent, even interactive communication with users, items which will determine the relational strategy. We have called this category (7) Communications.

Furthermore, we have decided to include some variables relating to the Website's design that, given the new medium's characteristics, are important in order to maintain communicative richness. We have included these variables in a category which, using IT jargon, we have called Usability (8).

In order to approach the second aim, and to gain knowledge of the causes that determine whether businesses have a corporate Website or not and given the fact that this is a new topic, at least with regard to the SME ambit, we have performed an exhaustive statistical analysis in order to obtain a first, explanatory, approach which clearly must not be understood as a search for factors that systematically lead to the adoption of a Website.

Therefore different univariate tests were performed in the search for factors that might possible explain a business' greater or lesser propensity to possess a corporate website and subsequently, with the aim of obtaining a complete and therefore more complete picture, we have undertaken a multivariate analysis using a logistic regression.

\subsection{Sample}

The chosen sample was a stratified random selection taken from the Spanish Balance Sheet Analysis System (SABE) database which is representative of the Central Directory of Businesses (DIRCE) provided by the Spanish Office National Statistics, taking into consideration the different strata of both sector and size. The chosen criteria was the most widely-used one in research works $\left(\mathrm{AECA}^{5}, 2001\right)$ and one which is equally used by the Spanish Ministry for Industry, Trade and Tourism through its General Directorate for SME Policy, considering any business with less than 250 employees to be an SME.

\footnotetext{
${ }^{5}$ The Spanish Association of Business Acounting and Administration
} 
The study was performed on a sample of 870 businesses enabling us to assume a sample error giving a 95\% level of confidence, something that is subsequently analysed in the summary table below:

\begin{tabular}{|c|c|c|}
\hline $\begin{array}{c}\text { Error Points } \\
\text { Percentage }^{1}\end{array}$ & Sample & $\begin{array}{c}\text { Maximum } \\
\text { Error }^{2}\end{array}$ \\
\hline $10 \%$ & 870 & $14.47 \%$ \\
\hline
\end{tabular}

Table 1: Sample errors

1 Error committed in each stratum (Sector-Size)

2 Maximum global error obtained when dividing by provinces by proportional affixation.

The distribution of the businesses by sector and size is as follows:

\begin{tabular}{|c|c|c|}
\hline Industrial & Construction & Services \\
\hline $42.3 \%$ & $26.6 \%$ & $31.1 \%$ \\
\hline
\end{tabular}

Table 2: Distribution by sector

\begin{tabular}{|c|c|c|}
\hline $\begin{array}{c}\text { Up to } 10 \\
\text { workers }\end{array}$ & $\begin{array}{c}11 \text { to } 50 \\
\text { workers }\end{array}$ & $\begin{array}{c}\text { More than } 50 \\
\text { workers }\end{array}$ \\
\hline $27.7 \%$ & $46.7 \%$ & $25.6 \%$ \\
\hline
\end{tabular}

Table 3: Distribution by size ( $\mathrm{n}^{\mathrm{o}}$ of workers)

In order to obtain information concerning the variables needed in this study, a survey aimed at business managers was drawn up. The survey, designed by a research team from the University of Cádiz, comprised several blocks of questions dealing with different SME-related topics. One of them in particular, included in the Appendix, was designed with the aim of gaining more in-depth knowledge when studying the use of Websites by SMEs.

The surveys were personal and performed by survey personnel belonging to a public organisation dedicated to encouraging business activity (IFA) and personnel from the company P-Value all of whom had previously been trained by the research team in order to homogenise the data-gathering criteria. As a result of the response index, our sample was reduced to 816 businesses. 


\subsection{Descriptive analysis}

During March 2004, an exhaustive web search using the most widely-used search engines in our geographical ambit concerning the businesses comprising the target sample was performed in order to locate their Websites. During the search the following difficulties were encountered:

The database contained a company name or a registered office that on occasion did not coincide with the trading name, making it impossible to find the Website.

Some businesses stated that they had a Website when in fact the Website belonged to the group or another business within the group.

Other businesses claimed to have a Website when in fact what they had was an entry in a company directory.

Having overcome these difficulties, we finally located 223 businesses excluding those whose Website was under construction as well as those that, even though their domain ownership was confirmed in WHOIS, did not have a Website. This is shown in the following summary table:

\begin{tabular}{|c|c|c|}
\hline No web & 557 & $68.26 \%$ \\
\hline Domain only & 15 & $1.84 \%$ \\
\hline $\begin{array}{c}\text { Under } \\
\text { construction }\end{array}$ & 25 & $3.06 \%$ \\
\hline Web & 219 & $26.84 \%$ \\
\hline & 816 & $100.00 \%$ \\
\hline
\end{tabular}

Table 4: Percentage of Websites

It is worthy of note that we believe that some companies have eliminated their Website, a suspicion that has arisen due to the fact that during the URL search process we have found references to URL's although at present there is no Website even though some businesses have maintained their domain. These disappearances have occurred in spite of Alles, Kogan and Vasarhelyi's statement that (2001) "once voluntary publication has been started, it can be very difficult to stop since to do so would probably be seen as a negative signal". 
With regard to the sectorial distribution, we would like to highlight the heterogeneous distribution of companies with Websites between sectors as can be observed in the following summary table, where the slightly lower use of Websites by the construction sector can be observed.

\begin{tabular}{|c|c|c|c|}
\hline & Businesses & With website & $\%$ \\
\hline Industrial & 343 & 120 & $39.65 \%$ \\
\hline Construction & 217 & 29 & $17.97 \%$ \\
\hline Services & 256 & 70 & $32.81 \%$ \\
\hline & 816 & 219 & \\
\hline
\end{tabular}

Table 5: Distribution of Website by Sector

Below is a similar table taking into consideration the number of employees where an increase in the percentage of Websites as the size of the SME increases can be observed.

\begin{tabular}{|c|c|c|c|c|c|c|c|c|}
\hline & \multicolumn{3}{|c|}{ From 1 to 10} & \multicolumn{3}{c|}{ From 11 to 50} & \multicolumn{4}{c|}{ More than a 50} & \\
\hline & NO & 176 & $69.02 \%$ & 229 & $67.95 \%$ & 152 & $67.86 \%$ & 557 \\
\cline { 2 - 10 } WEBSITE & YES & 79 & $30.98 \%$ & 108 & $32.05 \%$ & 72 & $32.14 \%$ & 259 \\
\hline & Total & 255 & $100.00 \%$ & 337 & $100.00 \%$ & 224 & $100.00 \%$ & 816 \\
\hline
\end{tabular}

Table 6: Distribution of Website by Size

With regard to the typology of the information displayed, (Table 1), we can observe a large preponderance of commercial aspects. The fact that $87 \%$ of the companies include information concerning their products, something that might appear reasonable if we bear in mind that commercial possibilities "are [those that are] most rapidly spotted by businesses when they believe that there is a large potential market" Soh et al., 1997). However, those businesses still do not make use of the Internet's multimedia potential and there are few businesses that include animation, three-dimensional graphics and other options that enable users to gain greater knowledge of the product in question.

Of great importance is the fact that businesses appear to be reluctant to publish product prices which, consequently, closes the door to the ability of making sales over the Internet. However, the very nature of certain products meaning that this option is undoubtedly not a viable one must also be taken into consideration.

Comparatively speaking, the financial content published is relatively scant (11.87\%), so scant that we have only found one consolidated balance sheet while 
only $5 \%$ of the businesses publish figures on turnover, corporate capital and, very rarely, profits. There is yet a further reduction (to $1.37 \%$ ) when considering the number of businesses that include series of financial data. It must be borne in mind that a large proportion of these businesses have a sole proprietor and that these businesses have a few close links with banks or indeed that there might be other circumstances that reduce the need to make their financial reporting public.

It is also worthy of note that businesses are still reluctant to publish information concerning their forecasts, objectives or future plans $(7.76 \%)$ and they are even less wiling to comment on their sector's difficulties or opportunities $(1.83 \%)$. We must however point out that a large number of businesses do refer to competitive advantages and intangible assets such as quality, technology, and experience etc., something perhaps that is evidence of the company's aim to reinforce its image.

It is equally noteworthy that the businesses' human resources are not the most important target user group for Andalusian SME's. We must note that $8.68 \%$, by accepting the sending of CVs, appear to use the Internet as an important way of recruiting personnel. Furthermore, the use of Intranets or private areas used by employees does not reach $6.85 \%$ of the sample.

With regard to environmental information, almost $11.42 \%$ of the businesses deal with the issue or show an interest in it although we are convinced that a sectorial analysis would shed greater light on the concentration of this aspect in certain sectors.

With respect to tools that help users browse the Website, around $15 \%$ use some of those mentioned in the study. While this is not an excessively high number, we do believe it is necessary to take into consideration the fact that the majority of these companies' Websites are simple pages with no more than five or six sections, something that in turn means that browsing them is not a highly complex operation.

We conclude that in spite of the fact that $92.69 \%$ of the Websites include elements of corporate information, only $10.5 \%$ do not make any reference at all to financial or commercial items or human resources, something that in our opinion demonstrates that use of the ornamental strategy is not common among Andalusian businesses. Therefore, with all of the pertinent reservations, we opine that not only 
do most of them want to have a URL for reasons of modernity or to imitate the competition, but their possession of a Website also obeys an objective or strategy. $46.12 \%$ include some of the items that we have regarded as informative but they do not include items of a relational nature while $43.38 \%$ of the businesses with Websites are clearly defined as having a more interactive strategy with their users. This can be observed in the following summary table:

\begin{tabular}{|c|c|c|}
\hline ORNAMENT AL & 23 & $10.50 \%$ \\
\hline INFORMATIVE & 101 & $46.12 \%$ \\
\hline RELATIONAL & 95 & $43.38 \%$ \\
\hline & 219 & $100.00 \%$ \\
\hline
\end{tabular}

Table 7: Strategic use of the website

The types of strategies examined are undoubtedly those detected via their Websites and that therefore there is no reason why they should coincide with the strategy that the business has defined with regard to its relationships with its stakeholders since there are many more channels of communication that this work does not take into consideration.

In this section, we would like to state that we are aware the limitations that we are assuming when attempting to reduce something as complex as the presentation of information by provided by businesses to statistical data Páez and Oviedo (2000). In this regard, we must say that many of the items analysed have been converted into duals, whether this dual exists or not, and without taking the quality of the information into account.

We do however believe that we have limited other criticisms that are usually levelled at this type of work such as the possible disparity of criteria due to the fact that several people have analysed the Websites and that the time elapsed between examining the first and last corporate Website might be considerable in terms of the growth and incorporation of information onto the said Websites. In order to avoid such criticism, this work has used only one person to review the Websites even when the criteria to be used had been clarified and agreed upon. The time used to review the Websites, once their addresses had been found, was ten days. 


\subsection{Univariate analysis}

\subsubsection{Variables and methodology}

As we have already mentioned, we opted in the particular case of the decision to create a Corporate Website for Thong's integrated model which specifies four contextual groups as determining factors in the decision. The subgroups of variables identified have their origin in directorial or management, innovation, organisational and environmental factors.

Taking the above model as our point of departure and using the data from the SABE database as well as the management survey undertaken, we have attempted to measure these variables. Table 8 shows Thong's original scheme, its correspondence with the variables that we have used and the scale of measurement.

In this regard, some clarifications need to be made. First, it has been impossible for us to measure and evaluate both the Manager's training and that of the employees in Information Systems; however, we have included the Manager's integrated training for reasons that will be established when presenting the hypotheses.

Taking this as the starting point, the methodology followed has a double axis. Initially, we will undertake a univariate analysis where we analyse the contingency relationship with the indicative Website possession variable of each of the variables defined previously.

In order to do this, different techniques have been used as a function of the existing data. A Pearson $\mathrm{X}^{2}$ (Table 9) for qualitative variables in order to analyse the degree of association between them test has been used and Cramer's V in order to verify the force of the above association.

When the explanatory variable is ordinal we have considered the use of this characteristic as reasonable in order to perform more efficient contrasts in order to better quantify the association when it exists and to aid its interpretation. In this regard, we have considered the use of the non-parametric test described by Mann-Whitney whose aim is to verify whether or not two independent samples (groups) come from one population as a suitable test. Moreover, we have also used other non-parametric association measurements for ordinal variables in these cases: Kendall's Tau-b in order to know the direction of the relationship between 
the variables, indicated by the coefficient's signal, and its magnitude shown by the absolutely valuable.

Finally, in order to reinforce the study, we have verified if the proportions of the two binomial distribution samples are statistically significant. In the case of ordinal variables and of the Likert scale, it has been necessary to transform them to a dichotomous scale, dismissing the central values in order to compare the proportion of answers between the group possessing Websites and the group without Websites.

A multivariate logistic analysis was then performed with the aim of obtaining the probability that an observation belongs to a specific group as a function of the explanatory variables that orient the said observation's values. In concrete terms, the aim of our logistic regression is to estimate the relationship between the explanatory variables and the dependent (possession of a Website or not) so that the more precise the estimation of the variables of interest's coefficients, the better the model will be.

First, and due to the demands of the model used the nominal variables had to be converted, as was the case of sectors and managers' training, into dichotomies (Sector1; Sector2; Sector3 and Formdir1; Formdir2; Formdir3).

Furthermore by having 5 indicators of the importance given by businesses to the commercial distribution process and, in an attempt not to lose information, we opted for taking the average of the five variables, given the homogeneity of the measurement scale. The resulting variable was called DC_average.

\subsubsection{Hypothesis}

In spite of basing the work on an adaptation of an integrating model, we believe the following hypotheses to be reasonable.

H1: Possessing a corporate Website is independent of the Manager's education and training

There is clear evidence to support the fact that individual differences influence the implantation of innovations as well as the fact that the higher the level of an individual's education, the greater his or her awareness of the opportunities 
presented by the new technologies should be (Raymond, 2001). Also must be added the fact that as Riemenschneider, Harrison and Mykytyn (2003) indicate, "in the case of SME's the decision to implant a Website is the responsibility of a single individual".

Moreover, it is clear that the ability to comprehend technology is related to the manager's basic education/training and thus Lal (2002) justifies the significance obtained by this variable through the Schumpeterian theory that the businessman or woman's innovative ability is the basis of a business' economic surge.

H2: Possessing a corporate Website is independent of the Manager's capacity to adapt to change and/or innovation

Using arguments that are similar to the above hypothesis and basing ourselves on the idea that the CEO's characteristics are crucial in determining the innovative attitude of small companies (Rizzoni, 1991), we contend that not only can education and training be a determining variable, but also when adopting a new technology his or her personal capacity to face change and new situations can be crucial.

H3: Possessing a corporate Website is independent of the company's size

The variable of size is usually taken into great account due to the fact that large companies have greater communicative needs and as such the Internet appears to be a good instrument for achieving this end. As Iacovou, Benbasat and Dexter (1995) argue, given small companies' scarce resources, such companies will have greater difficulty with maintenance costs when compared with companies of a larger dimension. Therefore the profits obtained increase as the size of the business increases. That, following Babio, Muiño and Vidal (2001), would lead to larger businesses having a greater interest in implanting and using this new media.

Most works find significant positive correlations (Liu et al., 1997; Ashbaugh, Johnstone and Warfield, 1999; Larrán and Giner, 2002; Teo and Tan, 1998; EllisChadwick, Doherty and Hart, 2002; Teo and Yujun, 2004) with regard to the fact that the larger the size of a company, the greater the likelihood that it will decide to implant a Website, even when in most cases they have used samples of stockmarket quoted companies.

H4: Possessing a corporate Website is independent of the sector to which the business belongs 
It would seem reasonable that in different sectors the motivation behind possessing a Website will be different and thus Lymer, Johnson and Baldwin-Morgan (1997) argue that service-sector businesses have a greater need to communicate their ideas and concepts than businesses producing physical objects.

Those studies, with exceptions, (Drew 2003), that classify businesses by sector in general terms and independently of the country or environment studied, detect differences between sectors with regard to possessing a corporate Website, Ellis-Chadwick, Doherty and Hart (2002). However, most works only refer to this variable for descriptive purposes, presenting the limitations of using this variable because of the difficulties involved in establishing an exact and significant classification due to the fact that the studies are obliged to reduce the sample groups considerably in order to increase the number of businesses belonging to each group (Bonsón and Escobar, 2002).

In our case, by using the SABE database the by-sector classification was the only option possible and thus any greater segmentation was impossible.

H5: Possessing a corporate Website is independent of environmental pressure

The variable of environmental pressure, especially from partners and competitors has been widely-used and thus Thong (1999) clearly argues that competition increases the probability of adopting an innovation, pushing businesses towards the use of Websites. This has been refuted in some works, although with regard to other types of innovations (Globerman, 1975; Levin, Levin and Meise (1984).

H6: Possessing a corporate Website is independent of the importance given to the quality of processes and products

Lal (1999) argues that it has been demonstrated that product quality is the most important origin of competitiveness. Other studies (Dosi et al., 1990; Pratten, 1991) along the same lines show that quality awareness within businesses makes them adopt new technologies more quickly. Taking this as our basis and given the technological nature of a Website, we believe that the presentation of the above hypothesis is justified. 
H7: Possessing a corporate Website is independent of the company's international orientation.

According to a study by the Spanish Chambers of Commerce Cámaras de Comercio, 2002), businesses with international commercial relationships are better adapted to the information society and are the businesses that will undoubtedly reap the greatest benefits from possessing a corporate Website. Lal's (2002) study, although concentrating more on e-commerce, presents more indicators with regard to the fact that companies with an international orientation have adopted more Internet tools.

H8: Possessing a corporate Website is independent of the importance given to the commercial distribution process

If a business foresees that it will obtain profits from possessing a Website, it will undoubtedly be motivated into taking the necessary steps to have one. When we refer to SME's, a large part of the literature Walczuch, Van Bravey Lundgren, 2000; Geiger and Martín, 1999; Soh et Al., 1997; Griffith and Krampf, 1998) states that the benefits reaped by a company are fundamentally of a commercial nature. We therefore opine that that we must analyse the possible causality of this variable as an incentive to possessing a corporate Website.

H9: Possessing a corporate Website is independent of the relationships that the business has with its clients and suppliers via the Internet

It is evident that compatibility, understood as the degree to which an innovation is perceived as being consistent with present values (Rogers, 1983), can be an element that helps the Manager to present a positive stance towards a new technology. In this regard, we believe that if businesses have some type of Internet contact with clients and suppliers, basically e-mail, it appears to be clear that by having an Internet connection, the incremental cost and the required knowledge to adopt a Website will be much less (Dholakia and Kshetri, 2004).

H10: Possessing a corporate Website is independent of the business' technological tradition

According to Iacovou, Benbasat and Dexter (1995) the technological tradition of businesses means that they do not feel intimidated by technology; rather they 
have a corporate overview with regard to information management and furthermore they have the necessary means for implanting it (computers, networks, etc.), the reason for which we consider it to be another of our working hypotheses.

\subsubsection{Results}

From the univariate analysis (Table 9) we can conclude that except for the Manager's capacity to adapt to innovation and the number of competitors, the rest of the variables are significantly different between those businesses using Web technology and those that do not. Although the analysis gives us a first approximation to the variables that can affect the fact of possessing a Website or not, the consideration that there are more complex circumstances that enable the different variables to interact through a multivariate analysis will allow us to accept or reject each of the above hypotheses.

The final binary logistic model (Table 10) was designed to emphasise the most significant effects and not in order to obtain a high prediction value ${ }^{6}$, thus enabling us to make the following statements with regard to the hypotheses expressed.

With regard to the Manager's education and training (H1), we can only conclude that those businesses whose Managers are included in the lower portion of education and training have a lower propensity to possess a corporate Website while the rest of the groups behave in a similar manner or at least there are no significant differences. This might perhaps help explain why some works cannot certify that this variable has a direct effect (Raymond 2001) and why others show a clear significance (Lal 2002).

The Managers' capacity to adapt to innovation (H2) does not appear to be a determining variable since it is not significant in either the individual correlations analysis or in the joint model. Neither have other studies been able to demonstrate this relationship (Raymond 2001).

As with other works, (Lal 2002) the relationship of size (H3) with the possession of a Website is confirmed. In the case of size, even when several variables have been

\footnotetext{
${ }^{6}$ However in Table 11 as a measurement of goodness of fit, the percentage of correct predictions that gives the estimation $(72.17 \%)$ is presented.
} 
tested, we have opted to use the Turnover Logarithm simply because it improves the model's results although in the model both the number of employees and total assets were equally significant.

The results obtained appear to confirm that Website distribution is related to the sector to which the businesses belong (H4). This statement must however be analysed from the perspective of the sectors established by the SABE database, from which the sample was extracted.

It is not possible to confirm the hypothesis regarding to what extent environmental pressure affects the lesser or greater propensity of businesses to possess a Website (H5) given the fact that both the univariate results and the results when taking the rest of the variables into account make such an affirmation inadvisable. What we can affirm however is that the idea that the variable used (number of competitors) measures the object phenomenon (degree of competition) with very little efficiency.

The relationship in the hypothesis concerning the importance given by businesses to the quality of processes and products (H6) as measured by the possession of an ISO 9000 series certification or equivalent appears to be evident, not only from a univariate perspective but it also becomes one of the model's most significant variables.

With regard to the fact that those businesses that are most internationally oriented have adopted corporate Websites to the greatest extent (H7), there is a clear relationship only when we consider both variables. However, the multivariate model does not include this variable with the necessary degree of significance. This circumstance does not appear to be compatible with other works (Lal, 2002) that do refute the null hypothesis. One possible cause might be the high degree of correlation that we have detected between this variable and the Manager's degree of education and training, causing multi-colinearity.

The results demonstrate that the commercial benefits perceived by SMEs with regard to their Websites (H8) are important given the fact that a significant positive association is demonstrated between the possession of a corporate Website and the five variables used for that purpose and equally the average of these variables presents a sufficiently significant variable in the multivariate analysis. 
It has been verified that those businesses that already have some sort of Internet contact with clients and suppliers (H9) take the step of possessing a Website more quickly. However, it must be added that there might be some cause - effect confusion between both variables.

Possessing a Website appears to be quite correlated with a business' technological tradition (H10) if we take into consideration investment in hardware as a measurement of this phenomenon, something that has already been demonstrated in other works of a similar nature (Iacovou, Benbasat and Dexter, 1995). However, we would like to add that by having measured the variable directly in euros, there might be a certain correlation with the size variable, requiring that the results be examined with a measure of caution.

\section{CONCLUSIONS AND SUBSEQUENT STUDIES}

The percentage of SMEs possessing a Website is still low (31.76\%) and we believe that with this work we have contributed a first approximation to the knowledge of those variables that might affect this process.

In this regard there appears to be a clear relationship between possessing a Website and the size, sector, Manager's education and training, having previous contacts with clients and/or suppliers via the Internet, as well as the businesses' technological tradition and the importance given to the quality of products as well as the commercial distribution process since they appear to demonstrate a significant relationship both in univariate and multivariate form.

Similarly, the internationalisation variable appears to be clearly correlated. However, when including it in the model, it appears not to be significant, something that we might attribute to its clear relationship with the Manager's education and training. In later studies this will have to be the subject of greater attention.

Finally the Manager's capacity to adapt and the degree of competition variables appear not to have a statistical correlation with the possession or not of a Website. Similarly, it would be advisable to examine this further, attempting to obtain precise indicators with the aim of being able to make more conclusive statements. 
With regard to the information content of the SMEs' Websites analysed, they have a simple profile, usually including a brief description or history of the business in question and its activities and with almost no mention of financial information. Usually however, there is a products section where there are more or less detailed photographs of the same, their characteristics and, at most, their principal qualities and characteristics.

In sum, this clear preponderance of commercial aspects, especially information concerning products, demonstrates a clear orientation of SMEs' Websites towards their clients but the fact that they do not publish prices nor enable clients to purchase directly leads us to think that the businesses' principal objective is to strengthen their image and that of their products yet without making a firm commitment to the possibilities offered by the Internet.

It would be of interest to follow these descriptive works up in order to improve our knowledge with regard to the businesses' rhythm of adaptation to this phenomenon as well as performing comparisons between different geographical ambits.

Moreover, we must also indicate that the theories upon which this work has been based are theories referring to individual decisions. These theories correspond to the SME ambit due to the fact that that the decision is typically taken by a single executive. We are however, aware, as Prescott and Conger indicate, that adoption studies should examine who within the organisation takes these decisions and how the decision is taken in order to improve knowledge of the phenomenon.

\section{REFERENCES}

AECA (2001): Factores Determinantes de la eficiencia y rentabilidad de la Pyme en España. Asociación Española de Contabilidad y Administración de Empresas. Madrid.

ALLES, M.; KOGAN, A.; VASARHELYI, M. (2001): "Feasibility and Economics of Continuous Assurance", Journal of Practice \& Theory, Vol. 21, n.1.

ASHBAUGH, H.; JOHNSTONE, K.M.; WARFIELD, T.D. (1999): “Corporate reporting on the internet", Accounting Horizons, Vol. 13: 241-257. 
AJZEN, I. (1991): "The Theory of planned behavior". Organizational Behavior and Human Decision Processes, Vol. 50, n. 2: 179-211.

BABIO ARCAY, Mª R.; MUIÑO VAZQUEZ, Mº F.; VIDAL LOPO, R. (2001): "Voluntary Disclosure in Spain: an investigation of preparers' perceptions". Paper presented at the 24th Annual Congress of the European Accounting Asocciation". Athens.

BONSÓN, E.; ESCOBAR, T. (2002): "El reporting digital en la Europa del Este e Islandia". Paper presented at the X "Encuentro de Profesores Universitarios de Contabilidad". Santiago de Compostela.

CAMARAS DE COMERCIO (2002): La adaptación de la empresa española a la sociedad de la información.

CHEUNG, W. M.; HUANG, W. (2002): “An investigation usage of the World Wide Web: a picture from Singapore", International Journal of Information Management, Vol. 22: 377-388.

CHWELOS, P., BENSABAT, I. and DEXTER, A. (2001): "Research report: empirical test of an EDI adoption model". Information Systems Research, Vol. 12, n. 3: 304-321.

CLARKSON, M. B. E. (1995): “A stakeholder framework for analyzing and evaluating corporate performance", The Academy of Management Review, Vol. 20(1), 92-117.

CRAGG, P. (1996): “Adoption of the Internet by Small Firms". Paper presented to the AusWeb The Second WorldWideWeb Conference.

DAVIS, F. (1989): "Perceived Usefulness, Perceived Ease Of Use, And User Acceptance", MIS Quarterly, Vol. 13, n. 3.: 319, 340.

DHOLAKIA, R. R.; KSHETRI, N. (2004): "Factors impacting the Adoption of the Internet among SMEs", Small Business Economics, Vol. 23: 311-322.

DOSI, G.; PAVITT, K..; SOETE, L. (1990): “The Economics of Technical Change and International Trade". Harvester Wheatsheaf. London 
DREW, S. (2003): "Strategic uses of E-commerce by SMEs in the East of England", European Management review, Vol. 21, n 1.: 79-88.

ELLIS-CHADWICK, F.; DOHERTY, N.; HART, C. (2002): "Signs of change? A longitudinal study of Internet adoption in the UK retail sector", Journal of Retailing and Consumer Services, Vol. 9.: 71-80.

FISHBEIN, M.; AJZEN, I. (1975): "Belief, attitude, intention and behavior: An introduction to theory and research". Addison Wesley. USA,.

GEIGER, S.; MARTÍN, S. (1999): "The Internet as a relationship marketing toolsome evidence from Irish companies”, Irish Marketing Review, Vol. 12. n. 2.

GLOBERMAN, S. (1975): "Technological diffusion in the Canadian tool and die industry". Review of Economics and Statistics, Vol. 57, n.. 4: 428-434.

GRANDON, E. E.; PEARSON, J. M. (2004): "Electronic commerce adoption: an empirical study of small and medium US businesses", Information and Management, Vol. 42, n.1: 197-216.

GRIFFITH, D. A.; KRAMPF, R. F. (1998): "An examination of the web-based strategies of the top 100 U S Retailers", Journal of Marketing: Theory and Practice, Summer:12-24.

HAMILL, J.; GREGORY, K. (1997): "Internet marketing in the internationalization of adopters and non-adopters of WWW", Journal of Marketing Management, Vol. 13 (1-3): 9-28.

HARRISON, D. A.; MYKYTYN, P.P.; RIEMENSCHNEIDER, C. K. (1997): "Executive decisions about adoption of information technology in small businesses: theory and empirical tests", Information Systems Research, Vol. 8, n. 2.: 171195.

HOWARTH, B. (1996): “Travelling business class”, IT Casebook Supplement to ComputerWorld, October, p. 24-29.

HUIZINGH, E. (2000): “The content and design of Web sites: an empirical study", Information \& Management, Vol. 37: 123-134. 
IACOVOU, C. L.; BENBASAT, I.; DEXTER, A.S. (1995): "Electronic data interchange and small organizations: adoption and impact of technology", MIS Quarterly, Vol. 19, n. 4: 465-485.

IGBARIA, M.; ZINATELLI, N.; CRAGG, P. (1997): Personal Computing Acceptance Factors in Small Firms : A Structural Equation Model, MIS Quarterly, Vol. 21, n. 3: 279-302.

KUAN, K.; CHAU, P. (2001): “A perception-based model of EDI adoption in small businesses using technology-organization-environment framework”, Information and Management, Vol. 38: 507-521.

KWON, T. H.; ZMUD, R. W. (1987): "Unifying the fragmented models of information systems implementation," in Critical Issues in Information Systems Research (Boland, R. and Hirscheim, R. eds), John Wiley, New York.

LAL, K. (1999): "Determinants of the adoption of Information Technology: a case study of electrical and electronic goods manufacturing firms in India", Research Policy, Vol. 28: 667-680.

LAL, K. (2002): "E-Business and manufacturing sector: A study of small and medium sized enterprises in India", Research Policy, Vol. 31, n. 7.

LARRÁN JORGE, M.; GINER INCHAUSTI, B. (2002): "The Use of the Internet for Corporate Reporting by Spanish Companies", The International Journal of Digital Accounting Research, Vol. 2, n. 1.

LEVIN, S. G.; LEVIN, S. L.; MEISEL, J. B. (1987): “A dynamic analysis of the adoption of a new technology: the case of optical scanners", Review of Economics and Statistics, Vol. 69, n. 1: 12-17.

LIU, C., ARNETT, K. P.; CAPELLA, L. M.; BEATTY, R. C. (1997): “Web sites of the Fortune 500 Companies: Facing customers through home pages", Information \& Management, Vol. 31: 335-345.

LYMER, A.; JOHNSON, R.; BALDWIN-MORGAN, A. (1997): “The Internet and small businesses: a study of impacts", paper presented at the $5^{\text {th }}$ European Conference on Information Systems. Cork. 
MEHRTENS, J.; CRAGG, P. B.; MILLS, A. M. (2001): “A model of Internet adoption by SMES", Information \& Management, Vol. 39: 165-176.

MIRCHANDANI, A. A.; MOTWANI, J. (2001): "Understanding small business electronic commerce adoption: an empirical analysis", Journal of Computer Information Systems, Spring: 70-73

NG, H. I, PAN, Y. J.; WILSON, T.D. (1998): "Business use of the world Wide Web: A Report on further investigations", International Journal of Information Management, Vol 18, n. 5.: 291-314.

PÁEZ SANDUBETE, J. M.; OVIEDO PRO, J. L. (2002): "Divulgación de información financiera, social y medioambiental a través de Internet por las empresas españolas que cotizan en bolsa". Paper persented at the XII "Congreso Asociación Española de Contabilidad y Administración de Empresas.

POON, S.; SWATMAN, P. M. C. (1995): 'The Internet for Small Businesses: An Enabling Infrastructure for Competitiveness', Proceedings of the Fifth Internet Society Conference, (ed.) Chon K., Hawaii, 221-231.

POON, S.; SWATMAN, P. M. C. (1997): "In-Depth Understanding on Issues Facing Small Business Internet Use: A Case Study Approach", Working Paper Series, Swinburne University of Technology, Australia.

PORTER, M.; MILlAR, V. (1985): "How information Gives you Competitive Advantage", Harvard Business Review, Vol. 63, n. 4: 149-160

PORTER, M. (2001): "Strategy and the Internet" Harvard Business Review, March, pp. 62-78.

PRATTEN, C. F. (1991): “The competitiveness of Small Firms”. Cambridge Univ. Press. Cambridge.

PRESCOTT, M.; CONGER, S.A. (1995): "Information Technology Innovations: a Classification by IT Locus of Impact and Research Approach”, DataBase Advances, Vol. 26, n. 2 \& 3: 21-41.

RAYMOND, L. (2001): "Determinants of web site implementation in small businesses", Internet Research, Vol. 11, n. 5.: 411-422 
RIEMENSCHNEIDER, C. K.; HARRISON, D. A.; MYKYTYN, P.P. (2003): "Understanding IT adoption decisions in small business: integrating current theories", Information and Management, Vol. 40: 269-285.

RIZZONI, A. (1991): "Technological innovation and small firms: a taxonomy", International Small Business Journal, Vol 9, n. 3.: 31-42.

ROGERS, E. M. (1983): "Diffusion of Innovations". $3^{\text {rd }}$ Ed. New York. Free Press.

SOH, CH. MAH, Q. Y. GAN. F. J. CHEW, D.; REID, E. (1997): “The use of the Internet for Business: the experience of early adopters in Singapore", Internet Research: Electronic Networking Applications and Policy, Vol. 7, n. 3.: 217-228

SPARKES, A.; THOMAS, B. (2001): "The use of the internet as a critical success factor for the marketing of Welsh agri-food SMEs in the twenty-first century", British food journal, Vol. 103, n 5: 331-347.

TEO, T. S. H.; TAN, M. (1998): "An empirical study of adoptors and non-adopters of the internet in Singapore”, Information \& Management, Vol. 34: 339-345.

TEO, T. S. H.; YUJUN, P. (2004): “A model for Web adoption”, Information \& Management, Vol. 41, n. 4.: 457-468.

THONG, J. Y. L (1999): “An integrated Model of Information Systems Adoption in Small Businesses". (1999), Journal of Management Information Systems, Vol. 153, n. 4.: 187-214.

WALCZUCH, R.; VAN BRAVE, G.; LUNDGREN, H. (2000): "Internet Adoption Barriers for Small Firms in The Netherlands", European Management Journal, Vol. 18, n. 5.: 561-572. 


\section{APPENDIX}

\begin{tabular}{|c|c|c|c|c|}
\hline \multicolumn{3}{|c|}{ A. ORNAMENTAL S TRATEGY } & & \\
\hline \multicolumn{3}{|c|}{ 1.- Corporate Information } & 203 & $92.69 \%$ \\
\hline & \multicolumn{2}{|l|}{ 1.1.- History } & 42 & $19.18 \%$ \\
\hline & \multicolumn{2}{|c|}{ 1.2. Geographical location } & 199 & $90.87 \%$ \\
\hline & \multicolumn{2}{|c|}{ 1.3.- General email address } & 159 & $72.60 \%$ \\
\hline & \multicolumn{2}{|c|}{ 1.4.- Organisational graphics } & 18 & $8.22 \%$ \\
\hline \multicolumn{3}{|c|}{ B. INFO RMATIVE S TRATEGY } & & \\
\hline \multicolumn{3}{|c|}{ 2.- Commercial Information } & 191 & $87.21 \%$ \\
\hline & \multicolumn{2}{|c|}{ 2.1.- Info. on products } & 191 & $87.21 \%$ \\
\hline & \multicolumn{2}{|c|}{ 2.1.- Private area for clients } & 18 & $8.22 \%$ \\
\hline & \multicolumn{2}{|c|}{ 2.3. - Commercial email } & 54 & $24.66 \%$ \\
\hline & \multicolumn{2}{|c|}{ 2.4. - Inclusion of photographs of } & 168 & $76.71 \%$ \\
\hline & \multicolumn{2}{|c|}{ 2.5. - Inclusion of animations } & 26 & $11.87 \%$ \\
\hline & \multicolumn{2}{|c|}{ 2.6. - Inclusion of product prices } & 14 & $6.39 \%$ \\
\hline \multicolumn{3}{|c|}{ 3.- Financial Information } & 26 & $11.87 \%$ \\
\hline & 3.1.- Annual ac & ounts & 1 & $0.46 \%$ \\
\hline & \multicolumn{2}{|c|}{ 3.2.- Financial figures } & 11 & $5.02 \%$ \\
\hline & \multicolumn{2}{|c|}{ 3.3.- Series of financial data } & 3 & $1.37 \%$ \\
\hline & \multicolumn{2}{|c|}{ 3.6.- Administrative email } & 22 & $10.05 \%$ \\
\hline \multicolumn{3}{|c|}{ 4- Strategic Information } & 99 & $45.21 \%$ \\
\hline & \multicolumn{2}{|c|}{ 4.1.- Information on aims and } & 17 & $7.76 \%$ \\
\hline & \multicolumn{2}{|c|}{ 4.2.- Information on competitive } & 90 & $41.10 \%$ \\
\hline & \multicolumn{2}{|c|}{ 4.3.- Information on the sector } & 4 & $1.83 \%$ \\
\hline \multicolumn{3}{|c|}{ 5.- Labour Information $\quad \mid$} & 39 & $17.81 \%$ \\
\hline & \multicolumn{2}{|c|}{ 5.1.- $\mathrm{N}^{\circ}$ of employees } & 11 & $5.02 \%$ \\
\hline & \multicolumn{2}{|c|}{ 5.2.- Human Resources Policy } & 7 & $3.20 \%$ \\
\hline & \multicolumn{2}{|c|}{ 5.3.- Offers of employment } & 19 & $8.68 \%$ \\
\hline & 5.4.- Private ar & a for employees & 15 & $6.85 \%$ \\
\hline 6.- Environm & al Information & & 25 & $11.42 \%$ \\
\hline & 6.1.- Environm & nt / surroundings & 25 & $11.42 \%$ \\
\hline C.RELATIO & L STRATEGY & & & \\
\hline 7.- Communi & & & 101 & $46.12 \%$ \\
\hline & 7.1.- Sending o & inions/suggestions & 82 & $37.44 \%$ \\
\hline & 7.2.- Newslette & Forum Subscription & 4 & $1.83 \%$ \\
\hline & 7.3.- News Sect & & 47 & $21.46 \%$ \\
\hline D. TECHNO & GICAL ITEMS & & & \\
\hline 8.- Usability & & & 33 & $15.07 \%$ \\
\hline & 8.1.- Site map & & 16 & $7.31 \%$ \\
\hline & 8.2.- Frequently & Asked Questions & 4 & $1.83 \%$ \\
\hline & 8.3.- Internal s & arch engine & 15 & $6.85 \%$ \\
\hline & 8.4.- Helpful lir & & 5 & $2.28 \%$ \\
\hline
\end{tabular}

Table 8. Percentages on the total of businesses with Websites analysed (219). 


\begin{tabular}{|c|c|c|c|}
\hline \multicolumn{2}{|c|}{ CHARAC TERIS TICS OF THE O RGANIS ATIO N'S LEADER } & $\begin{array}{c}\text { NAME O F } \\
\text { VARIABLES }\end{array}$ & SCALE \\
\hline \multirow{3}{*}{$\begin{array}{l}\text { MANAGER'S EDUCATION } \\
\text { AND T RAINING }\end{array}$} & MANAGER'S EDUCATION & \multirow{3}{*}{ FORMDIR } & \multirow{3}{*}{$\begin{array}{l}\text { 1: Primary Education } \\
\text { 2:Baccalaureate, rofessional training or } \\
\text { non-degree higher education } \\
\text { 3: University degree } \\
\end{array}$} \\
\hline & AND TRAINING & & \\
\hline & & & \\
\hline \multirow{2}{*}{$\begin{array}{l}\text { MANAGER'S ATTITUDE } \\
\text { TOWARDS INNOVAT ION }\end{array}$} & MANAGER'S CAPACITY & \multirow{2}{*}{ ADAPT ACA } & \multirow{2}{*}{ Scale of 1 to 4} \\
\hline & TO ADAPT TO CHANGES & & \\
\hline \multicolumn{4}{|c|}{ CHARAC TERIS TICS OF THE O RGANIS ATION } \\
\hline \multirow{3}{*}{ SIZE } & \multirow{3}{*}{ SIZE } & \multirow{3}{*}{ SIZE } & Number of employees \\
\hline & & & Total Assets \\
\hline & & & Turnover \\
\hline $\begin{array}{l}\text { EMPLOYEES' KNOWLEDGE } \\
\text { OF IT SYSTEMS }\end{array}$ & - & - & - \\
\hline \multirow{3}{*}{ INFORMATIVE INTENSITY } & \multirow{3}{*}{ SECTOR } & \multirow{3}{*}{ SECTOR } & 1. Industry \\
\hline & & & 2. Services \\
\hline & & & 3. Construction \\
\hline \multicolumn{4}{|c|}{ ENVIRO NMENTAL CHARAC TERIS TICS } \\
\hline \multirow{2}{*}{ SCALE OF COMPETITION } & NUMBER OF & \multirow{2}{*}{ NCOMP } & 0 Few competitors \\
\hline & COMPETITORS & & 1 Many competitors \\
\hline \multicolumn{4}{|c|}{ CHARAC TERIS TICS OF THE INNOVATION } \\
\hline \multirow{2}{*}{$\begin{array}{l}\text { RELATIVE ADVANT AGES OF } \\
\text { INNOVATION }\end{array}$} & \multirow{2}{*}{ QUALITY } & \multirow{2}{*}{ CERTISO } & \begin{tabular}{|lllll}
0 & does not & possess & ISO & 9000 \\
Certification & & & \\
\end{tabular} \\
\hline & & & 1 does possess ISO 9000 Certification. \\
\hline & \multirow[t]{2}{*}{ INTERNATIONALISATION } & \multirow[t]{2}{*}{ INTERNAC } & $\begin{array}{ll}0 & \text { if the business has not } \\
\text { internationalised }\end{array}$ \\
\hline & & & 1 if the business has internationalised. \\
\hline & \multirow{6}{*}{$\begin{array}{c}\text { IMPORT ANCE GIVEN TO } \\
\text { COMMERCIAL DIST RIBUT ION } \\
\text { PROCESS }\end{array}$} & & Scale of 1 to 5 \\
\hline & & IMPMARID & Effort to achieve an identifiable brand \\
\hline & & IMPCADIS & Influence on distribution channels \\
\hline & & IMPINNMK & $\begin{array}{l}\text { Innovation in marketing techniques and } \\
\text { methods }\end{array}$ \\
\hline & & IMPPRPUB & $\begin{array}{l}\text { Promotion and publicity above the } \\
\text { sector average }\end{array}$ \\
\hline & & IMPCAPUB & $\begin{array}{l}\text { Effort to improve the quality of } \\
\text { publicity }\end{array}$ \\
\hline \multirow[t]{2}{*}{ COMPATIBILIT Y } & $\begin{array}{l}\text { RELAT IONSHIPS WIT H SUPPLIERS } \\
\text { AND/OR CLIENTS VIA T HE }\end{array}$ & \multirow[t]{2}{*}{ RELINTER } & 0 Does not maintain relationships \\
\hline & & & 1 Does not maintain relationships \\
\hline COMPLEXITY & $\begin{array}{c}\text { BUSINESS' TECHNOLOGICAL } \\
\text { TRADIT ION }\end{array}$ & INVHARDW & $\begin{array}{l}\text { Investment in Hardware in the last two } \\
\text { years }\end{array}$ \\
\hline
\end{tabular}

Table 9 


\begin{tabular}{|c|c|c|c|c|c|c|c|c|c|c|c|c|}
\hline $\begin{array}{c}\text { Univariate } \\
\text { Analysis }\end{array}$ & mean & median & CHI^2 $^{\prime}$ & p-value & $\begin{array}{c}\text { V } \\
\text { Cramer }\end{array}$ & $\begin{array}{c}\text { Approx. } \\
\text { Sig. }\end{array}$ & Tau-b & $\begin{array}{c}\text { Approx } \\
\text { Sig. }\end{array}$ & $\begin{array}{c}\text { U-Mann- } \\
\text { Whitney }\end{array}$ & Sig. & $\begin{array}{c}\text { Calculate } \\
\mathrm{d} \text { Z }\end{array}$ & p-value \\
\hline FORMDIR & 2.230 & 2.000 & 33.89 & 0.000 & 0.208 & 0.000 & 0.184 & 0.000 & 50973.5 & 0.000 & 482.775 & 0.000 \\
\hline ADAPT ACA & 3.381 & 3.000 & 3.279 & 0.351 & 0.065 & 0.351 & 0.052 & 0.138 & 60326 & 0.136 & 0.000 & 1.000 \\
\hline NUMPL00 & 40.252 & 20.000 & - & - & - & - & - & - & 21850.5 & 0.000 & - & - \\
\hline LNT OT ACT & 13.775 & 14.149 & - & - & - & - & - & - & 34857.5 & 0.000 & - & - \\
\hline LNCNEG & 14.124 & 14.492 & - & - & - & - & - & - & 35573.5 & 0.000 & - & - \\
\hline SECTOR & 1.955 & 2.000 & 31.598 & 0.000 & 0.198 & 0.000 & - & - & - & - & - & - \\
\hline NCOMP & 0.794 & 1.000 & 0.195 & 0.362 & 0.016 & 0.659 & -0.016 & 0.662 & - & - & -0.646 & 0.518 \\
\hline INVHARDW & 1.307 & 1.000 & 48.343 & 0.000 & 0.262 & 0.000 & 0.249 & 0.000 & 42583 & 0.000 & 4.508 & 0.000 \\
\hline CERT ISO & 0.227 & 0.000 & 72.178 & 0.000 & 0.311 & 0.000 & 0.311 & 0.000 & - & - & 8.496 & 0.000 \\
\hline INTERNAC & 0.153 & 0.000 & 22.778 & 0.000 & 0.177 & 0.000 & 0.177 & 0.000 & - & - & 4.882 & 0.000 \\
\hline IMPMARID & 3.994 & 4.000 & 13.987 & 0.007 & 0.137 & 0.007 & 0.108 & 0.001 & 52358.5 & 0.001 & -3.383 & 0.000 \\
\hline IMPCADIS & 3.507 & 4.000 & 21.279 & 0.000 & 0.173 & 0.000 & 0.102 & 0.002 & 48945 & 0.003 & 4.982 & 0.000 \\
\hline IMPINMK & 3.429 & 3.000 & 33.017 & 0.000 & 0.214 & 0.000 & 0.160 & 0.000 & 46162 & 0.000 & -3.458 & 0.000 \\
\hline IMPRPUB & 3.114 & 3.000 & 29.497 & 0.000 & 0.200 & 0.000 & 0.159 & 0.000 & 47368 & 0.000 & -3.136 & 0.001 \\
\hline IMPCAPUB & 3.026 & 3.000 & 23.296 & 0.000 & 0.179 & 0.000 & 0.147 & 0.000 & 47361.5 & 0.000 & 3.966 & 0.000 \\
\hline RELINTER & 0.636 & 1.000 & 60.213 & 0.000 & 0.284 & 0.000 & 0.284 & 0.000 & - & - & 7.686 & 0.000 \\
\hline
\end{tabular}

Table 10

\begin{tabular}{|c|c|c|c|c|}
\hline Variable & Coefficient & Std. Error & z-Statistic & Prob. \\
\hline$\overline{\mathrm{C}}$ & -5.631 .876 & 1.254 .420 & -4.489 .625 & 0.0000 \\
\hline FORMDIR1 & -0.679812 & 0.321310 & -2.115 .753 & 0.0344 \\
\hline FORMDIR2 & -0.317315 & 0.290884 & -1.090 .865 & 0.2753 \\
\hline ADAPT ACA & 0.028381 & 0.184629 & 0.153719 & 0.8778 \\
\hline LNCNEG & 0.123333 & 0.056216 & 2.193 .913 & 0.0282 \\
\hline SECT OR2 & 0.630248 & 0.277110 & 2.274 .363 & 0.0229 \\
\hline SECT OR3 & -0.339246 & 0.326372 & -1.039 .446 & 0.2986 \\
\hline NCOMP & 0.287550 & 0.293763 & 0.978852 & 0.3277 \\
\hline CERTISO & 0.920702 & 0.247799 & 3.715 .525 & 0.0002 \\
\hline INTERNAC & 0.225151 & 0.301797 & 0.746034 & 0.4556 \\
\hline DC_AVERAGE & 0.512704 & 0.140179 & 3.657 .496 & 0.0003 \\
\hline RELINTER & 1.024 .025 & 0.264095 & 3.877 .485 & 0.0001 \\
\hline INVHARDW & 0.274656 & 0.143116 & 1.919 .108 & 0.0550 \\
\hline Mean dependent var & 0.389381 & \multicolumn{2}{|c|}{ S.D. dependent var } & 0.488150 \\
\hline S.E. of regression & 0.433664 & \multicolumn{2}{|c|}{ Akaike info criterion } & 1.139 .781 \\
\hline Sum squared resid & 8.256 .042 & \multicolumn{2}{|c|}{ Schwarz criterion } & 1.258 .095 \\
\hline Log likelihood & -2.445 .905 & \multicolumn{2}{|c|}{ Hannan-Quinn criter. } & 1.186 .404 \\
\hline Restr. log likelihood & -3.021 .485 & \multicolumn{2}{|c|}{ Avg. log likelihood } & -0.541129 \\
\hline LR statistic (12 df) & 1.151 .161 & \multicolumn{2}{|c|}{ McFadden R-squared } & 0.190496 \\
\hline Probability(LR stat) & 0.000000 & & & \\
\hline Obs with Dep $=0$ & 276 & \multicolumn{2}{|l|}{ Total obs } & 452 \\
\hline Obs with Dep=1 & 176 & & & \\
\hline
\end{tabular}




\begin{tabular}{|c|c|c|c|c|c|c|}
\hline \multicolumn{7}{|c|}{ Dependent Variable: WEB } \\
\hline \multicolumn{7}{|c|}{ Method: ML - Binary Logit } \\
\hline \multicolumn{7}{|c|}{ Date: 04/26/05 Time: 00:45 } \\
\hline \multicolumn{7}{|c|}{ Simple(adjusted): 33815} \\
\hline \multicolumn{7}{|c|}{ Included observations: 452} \\
\hline \multicolumn{7}{|c|}{ Excluded observations: 331 after adjusting endpoints } \\
\hline \multicolumn{7}{|c|}{ Prediction Evaluation (success cut off $\mathrm{C}=0.5$ ) } \\
\hline & \multicolumn{3}{|c|}{ Estimated Equation } & \multicolumn{3}{|c|}{ Constant Probability } \\
\hline & Dep $=0$ & Dep $=1$ & Total & Dep $=0$ & Dep $=1$ & Total \\
\hline$\overline{\mathrm{P}(\mathrm{Dep}=1)<=\mathrm{C}}$ & 228 & 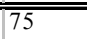 & 303 & 276 & 176 & 452 \\
\hline $\mathrm{P}(\mathrm{Dep}=1)>\mathrm{C}$ & 48 & 101 & 149 & 0 & 0 & 0 \\
\hline Total & 276 & 176 & 452 & 276 & 176 & 452 \\
\hline Correct & 228 & 101 & 329 & 276 & 0 & 276 \\
\hline$\%$ Correct & 82.61 & 57.39 & 72.79 & 100.00 & 0.00 & 61.06 \\
\hline$\%$ Incorrect & 17.39 & 42.61 & 27.21 & 0.00 & 100.00 & 38.94 \\
\hline Total Gain* & -17.39 & 57.39 & 11.73 & & & \\
\hline \multirow[t]{3}{*}{ Percent Gain** } & NA & 57.39 & 30.11 & & & \\
\hline & \multicolumn{3}{|c|}{ Estimated Equation } & \multicolumn{3}{|c|}{ Constant Probability } \\
\hline & Dep $=0$ & Dep $=1$ & Total & Dep $=0$ & Dep $=1$ & Total \\
\hline $\mathrm{E}(\#$ of Dep $=0)$ & 193.54 & 82.46 & 276.00 & 168.53 & 107.47 & 276.00 \\
\hline $\mathrm{E}(\#$ of Dep=1) & 82.46 & 93.54 & 176.00 & 107.47 & 68.53 & 176.00 \\
\hline Total & 276.00 & 176.00 & 452.00 & 276.00 & 176.00 & 452.00 \\
\hline Correct & 193.54 & 93.54 & 287.08 & 168.53 & 68.53 & 237.06 \\
\hline$\%$ Correct & 70.12 & 53.15 & 63.51 & 61.06 & 38.94 & 52.45 \\
\hline$\%$ Incorrect & 29.88 & 46.85 & 36.49 & 38.94 & 61.06 & 47.55 \\
\hline Total Gain* & 9.06 & 14.21 & 11.07 & & & \\
\hline Percent Gain** & 23.27 & 23.27 & 23.27 & & & \\
\hline
\end{tabular}

Table $12 *$ Change in "\% Correct" from default (constant probability) specification **Percent

\section{SURVEY}

\section{MANAGER'S TRAINING/EDUCATION}

A) What is the CEO or manager's level of training/education ?
a) Primary School, general knowledge
b) Baccalaureate/vocational training or non-degree level tertiary education
c) University degree

\section{ATTITUDE TOWARDS INNOVATIONS}

B) Do you regard yourself as being open to change?
a) No, a little, occasionally
b) Quite, often or always 


\section{LEVEL OF COMPETITION}

C) In your sector there are:
a) A lot of competitors
b) Few competitors

\section{RELATIVE ADVANTAGES OF INNOVATION}

D) Does your business have a 9000-series ISO certification or its equivalent?
a) Yes
b) $\mathrm{No}$

E) Has your business internationalised in the last two years?
a) Yes
b) $\mathrm{No}$

F) Indicate how important you feel the following factors to be in the development and success of your business

\begin{tabular}{|c|c|c|c|c|c|}
\hline \multirow[b]{2}{*}{ Effort to achieve a recognisable brand } & \multicolumn{3}{|c|}{ Not Important } & \multicolumn{2}{|c|}{ Very Important } \\
\hline & 1 & 2 & 3 & 4 & 5 \\
\hline Influence in distribution channels & 1 & 2 & 3 & 4 & 5 \\
\hline Innovation in the manufacturing process & 1 & 2 & 3 & 4 & 5 \\
\hline Innovation in marketing techniques and methods & 1 & 2 & 3 & 4 & 5 \\
\hline Promotion and publicity above the sector average & 1 & 2 & 3 & 4 & 5 \\
\hline Efforts to improve the quality of your publicity & 1 & 2 & 3 & 4 & 5 \\
\hline
\end{tabular}

\section{COMPATIBILITY}

G) Do you have a relationship with your suppliers and clients via the Internet?
a) Yes
b) $\mathrm{No}$

\section{COMPLEXITY}

H).- How much has your business invested in Hardware over the last two years?

$€ 0$ to $€ 30,000 \quad € 30,000$ to $€ 60,000 \quad € 60,000$ to $€ 90,000 \quad$ Over $€ 90,000$

